\title{
PEREMPUAN DAN PENDIDIKAN ANAK USIA DINI
}

\author{
Oleh: Wardana
}

\begin{abstract}
:
This paper examines the neighbors of women and early childhood education. Early childhood is a group of children who are in the process of growth and development that is unique, in the sense of having a pattern of growth and development (fine and coarse motor coordination), intelligence (thinking power, creativity, emotional intelligence, and spiritual intelligence), emotional social ( Attitudes and practices and religions), language and communication that are specific to the level of growth and development of children. Early childhood learning activities include aspects, morals, religion, discipline, language ability, thinking power, creativity, emotion, social skills, socializing, and skills. The Role of Women in Early Childhood Education is nurturing; Give birth, nurture and nurture children, teach children about manners based on religious norms. The most influential person in performing character formation is the mother who gave birth to them and PAUD teachers who are generally women.
\end{abstract}

\section{Abstrak:}

Tulisan ini mengkaji tetang perempuan dan pemdidikan anak usia dini. Anak usia dini adalah kelompok anak yang dalam proses pertumbuhan dan perkembangan yang bersifat unik, dalam arti memiliki pola pertumbuhan dan perkembangan (koordinasi motorik halus dan kasar), intelegensi (daya pikir, daya cipta, kecerdasan emosi, dan kecerdasan spiritual), sosial emosional (sikap dan perlaku serta agama), bahasa dan komunikasi yang khusus sessuai dengan tingkat pertumbuhan dan perkembangan anak. Kegiatan belajar anak usia dini meliputi aspek, moral, agama, disiplin, kemampauan berbahasa, daya pikir, daya cipta, emosi, kemampuan bermasyarakat, bersosialisasi, dan keterampilan.

Peran Perempuan dalam pendidikan Anak Usia Dini melipuiti; melahirkan, membina dan mengasuh anak, mengajarkan anak tentang sopan santun yang berdasarkan norma-norma agama. Orang paling berpengaruh dalam melakukan pembentukan karakter tersebut adalah ibu yang melahirkan mereka dan guru PAUD yang umumnya perempuan.

\section{Kata kunci: perempuan, ibu, pendidikan anak usia dini (PAUD)}

\section{A. PENDAHULUAN}

Diskursus mengenai perempuan tetap menjadi kajian menarik sepanjang sejarah intelektual umat manusia dari zaman ke zaman. Mulai sejarah perempuan dipandang tidak memiliki kemanusiaan yang utuh (Yunani Kuno dan Romawi abad ke-5 - abad ke-7 M), karena diyakini sebagai makhluk pembawa sial, sehingga eksistensinya dianggap sebagai aib dalam keluarga yang akan mendatangkan kemelaratan, hingga perempuan super modern saat ini justru menjadi objek kepentingan komersial yang senantiasa dicari dan dipuja, untuk kepentingan kehidupan hedonist. Oleh karena itu, sepanjang sejarah perempuan, kiprahnya 
dalam arena kehidupan terkadang sebagai pecundang kehidupan, dan pada saat bersamaan terkadang pula sebagai srikandi hingga sebagai pahlawan terhadap pihak lain.

Islam secara bertahap mengembalikan hak-hak perempuan sebagai manusia yang merdeka dalam menyuarakan keyakinannya, mengaktualisasikan karyanya, dan mengekspresikan dirinya serta sejumlah hak-hak lainnya. Terbukti dengan jelas pada masa Rasulullah perempuan telah tampil sebagai manusia yang sempurna setara dengan kaum lakilaki. Perempuan yang aktif, sopan, tetapi tetap terpelihara akhlaknya. Dalam naungan perlindungan dan jaminan al-quran perempuan dapat memasuki semua sektor kehidupan masyarakat, seperti politik, pendidikan, Ulama dalam berbagai bidang keilmuan, ekonomi, hukum dan berbagai sektor publik lainnya. ${ }^{1}$

Salah satu peran publik perempuan, baik sebagai pribadi maupun sebagai kelompok organisasi, yang tak dapat disangkal adalah kiprahnya dalam sektor pendidikan. Telah tercatat dengan jelas bahwa organisasi perempuan yang pertama mendirikan lembaga Pendidikan Anak Usia Dini pada tahun 1919 yakni Organisasi Aisyiyah², yang merupakan cikal berdirinya lembaga pendidikan Usia dini di seluruh nusantara. Ini menyiratkan bahwa kaum perempuan (baca: perempuan) telah memberikan kontribusi aktif dalam dunia pendidikan, terutama pendidikan Islam. ${ }^{3}$

Secara fenomenal bahwa sektor pendidikan yang dilaksanakan selama ini khususnya di Indonesia, tenaga pendidik didominasi oleh kaum perempuan, meskipun belum ada penelitian yang akurat yang mencatat keterlibatan kaum perempuan dalam dunia pendidikan mayoritas tenaga pendidiknya adalah kaum perempuan. Apakah hal ini disebabkan karena perempuan memiliki naluri keibuan yang senantiasa mengedepankan aspek emosionalnya dalam beriinteraksi dengan manusia lainnya terutama pada anak usia dini, atau ada aspek lain yang turut mempengaruhi sehingga perempuan lebih banyak berkiprah sebagai tenaga pendidik atau guru dibandingkan dengan profesi lainnya.

Sekaitan dengan pernyatan tersebut, menurut Quraisy Shihab Ibu (baca: perempuan) dalam bahasa al-Quran dinamai dengan umm. Dari akar kata yang sama dibentuk akata imam

\footnotetext{
${ }^{1}$ Suara Aisyiyah (Ed. Juli; 2015), h. 5.

2 Organisasi Aisyiyah adalah organisasi perempuan, yang merupakan organisasi otononm dalam organisasi Muhammadiyah. Organisasi ini dinisbatkan pada salah satu istri Rasulullah yakni Aisyah ra. Yang dismbolkan sebagai perempuan cerdas, selain berkiprah di ranah domestik, juga berkiprah dalam ranah publik, serta mendampingi Rasulullah dalam jangka waktu lama sejak perjuangan Rasulullah menyebarkan ajaran Islam, tampa mengabaikan peran-peran penting istri-istri Rasulullah yang lain. Suara Aisyiyah, (Ed.7: 2015), h. 4.

${ }^{3}$ Kata Islam dalam pendidikan Islam menunjukkan warna pendidikan tertentu, yaitu pendidikan yang berwarna Islam, pendidikan yang Islami, yaitu pendidikan yang berdasarkan ajaran Islam. Ahmad Tafsir, Ilmu Pendidikan dalam Perspektif Islam ( Cet.III; Remaja Rosda Karya: Bandung: 2000), h. 24.
} 
(pemimpin) dan umat. Kesemuanya bermuara pada makna "yang dituju" atau "yang diteladani”, dalam arti pandangan harurus tertuju pada umat, pemimpin, dan ibu untuk diteladani. Umm atau "ibu"melalaui perhatiannya kepada anak serta keteladanannya, dapat menciptakan pemimpin-pemimpin dan bahkan dapat membina umat. Sebaliknya, jika yang melahirkan seorang anak yang tidak berfungsi sebagai umm, maka umat akan hancur dan pemimpin (imam) yang wajar untuk diteladani tidak akan lahir. ${ }^{4}$ Dari pernyataan tersebut dapat dipahami bahwa kaum secara kodrati kaum perempuan tidak hanya dibebani untuk mengandung dan melahirkan anak, akan tetapi sekaligus dibebani tugas untuk menciptakan pemimpi-pemimpin umat.

Oleh karena itu, fungsi keibuan seorang perempuan diyakini akan mencetak pemimpin masa depan yang paripurna. Melalui upaya pendidikan seorang perempuan dengan cara mengajar, membimbing, melatih, membiaskan dan lain sebagainya dengan penuh kasih sayang, maka segala potensi kemanusiaan anak manusia akan tumbuh kembang sebagaimana mestinya. Demikian pula ketika peran pendidik yang diperankan oleh kaum perempuan dalam lingkungan pendidikan formal, terutama pada lembaga Pendidkan Anak Usia Dini, anak akan tumbuh kembang berdasarkan fase-fase alamiah seorang manusia baik secara fisik maupun psikis secara harmonis dan seimbang.

Sementara Pendidikan anak Usia Dini merupakan suatu hal yang sangat urgen pada setiap tahapan kehidupan manusia, karena pada masa inilah anak manusia mengalami masa yang sangat strategis dan efektif dalam menanaman nilai-nilai agama dan norma-norma sosial. Dengan kata lain bahwa masa ini disebut dengan the golden age, segala rangsangan akan direspon dengan jelas, dan tepat. ${ }^{5}$ Karena pada masa ini, anak menjadi meniru ulung dan merekam segala peristiwa yang dilihat dan didengar serta yang ia rasa. Pada saat inilah dibutuhkan pendidik yang tepat, memiliki jiwa atau naluri keibuan yang dapat menumbuhkembangkan segala potensi kemanusiaan pada anak sejak dini.

\section{PEMBAHASAN}

\section{A. Pendidikan Anak Usia Dini}

Anak usia dini adalah kelompok manusia yang berusia 0-6 tahun berdasrkan UUD RI no 20 2003 tentang Sistem Pendidikan Nasional. Para pakar pendidikan anak, mengatakan bahwa anak usia dini adalah kelompok anak yang dalam proses pertumbuhan dan perkembangan yang bersifat unik,

\footnotetext{
${ }^{4}$ Quraish Shihab, Lentera Al-Quran Kisah dan Hikamh Kehidupan (Cet.I; Mizan Pustaka: Bandung: 2008), h. 211.

${ }^{5}$ Jasmani. Lihat, Mansur, Pendidikan anak Usia Dini (Cet. II; Pustaka Pelajar: Yogyakarta: 2007), h. 19.
} 
dalam arti memiliki pola pertumbuhan dan perkembangan (koordinasi motorik halus dan kasar), intelegensi (daya pikir, daya cipta, kecerdasan emosi, dan kecerdasan spiritual), sosial emosional (sikap dan perlaku serta agama), bahasa dan komunikasi yang khusus sessuai dengan tingkat pertumbuhan dan perkembangan anak. Pendidikan anak Usia Dini, menurut Peraturan Pemerintah RI nomor 27 tahun 1990, tentang pendidikan pra sekolah, bahwa kegiatan belajar anak usia dini meliputi aspek, moral, agama, disiplin, kemampauan berbahasa, daya pikir, daya cipta,, emosi, kemammpuan bermasyarakat, sosial, keterampilan.

Dalam pendidikan Anak Usia Dini ada berbagai bentuk kurikulum yang dikembangkan oleh para ahli dalam pendidikan anak usia dini. Ada yang disebut dengan Kurikulum terpisah-pisah, yakni kurikulum mempunyai mata pelajaran yang tersendiri satu dengan lainnya tidak ada kaitannya, karena masing-masing mata pelajaran mempunyai organisasi yang terintegrasikan. Ada pula Kurikulum saling berkaitan, yakni antara masingmasing mata pelajaran ada keterkaitan, antara dua mata pelajaran masih ada kaitannya. Dengan demikian anak mendapat kesempatan untuk melihat keterkaitan antara mata pelajaran, sehingga anak masih dapat belajar mengintegrasikan walaupun hanya antara dua mata pelajaran. Kemudian ada pula yang dinamai dengan Kurikuluim Terintegrasikan, dalam kurikulum ini anak mendapat pengalaman luas, karena antara satu mata pelajaran dengan mata pelajaran lain saling berkaitan. Dalam kaitannya dengan materi pendidikan untuk anak usia dini, Ibnu Sina telah menyebutkan dalam bukunya yang berjudul As-Siyasah, ide-ide yang cemerlang dalam mendidik anak. Dia menasihati agar dalam mendidik anak dimulai dengan mengajarkannya al Qur'an al-Karim yang merupakan persiapan fisik dan mental untuk belajar. Pada waktu itu juga anak-anak belajar mengenal huruf-huruf hijaiyah, cara membaca, menulis dan dasar-dasar agama. Setelah itu mereka belajar meriwayatkan sya'ir yang dimulai dari rojaz kemudian qashidah karena meriwayatkan dan menghafal rojaz lebih mudah sebab bait-baitnya lebih pendek dan wajn (timbangan)nya lebih ringan. Sebaiknya dalam hal ini, guru memilih sya'ir tentang adab-adab yang terpuji, kemuliaan orang-orang yang berilmu dan hinanya orang-orang yang bodoh, mendorong untuk berbakti kepada orang tua, anjuran melakukan amar ma'ruf dan memuliakan tamu. Apabila anak-anak sudah bisa menghafal Al-Qur'an al-Karim dan mengetahui qaidah-qaidah bahasa Arab dengan baik, maka untuk mengarahkan ke jenjang berikutnya adalah dengan melihat kecenderungannya atau apa yang sesuai dengan tabiat dan bakatnya. Di dalam nasihat terakhir tersebut Ibnu Sina menyebutkan pengarahan guru yang disesuaikan dengan kecenderungan atau apa yang sesuai dengan bakat anak, merupakan ruh (inti) pendidikan modern di jaman kita ini. Para pakar pendidikan sekarang mengajak untuk selalu memperhatikan kesiapan dan kecenderungan 
anak-anak didik dalam belajar, mereka diarahkan ke dalam masalah teori maupun praktik yang meliputi masalah adab, olah raga, agama, sosial dan kesenian sesuai dengan kecenderungan mereka, agar mereka sukses dalam belajarnya. ${ }^{6}$ Dengan demikian seluruh mata pelajaran merupakan satu kesatuan yang utuh atau bulat. Adapun pokok-pokok pendidikan yang harus diberikan kepada anak, adalah meliputi seluruh ajaran Islam yang secara garis besar dapat dikelompokan menjadi tiga, yakni, aqidah, ibadah dan akhlak serta dilengkapi dengan pendidikan membaca Al Qur'an.

a. Pendidikan akidah, hal ini diberikan karena Islam menempatkan pendidikan akidah pada posisi yang paling mendasar, terlebih lagi bagi kehidupan anak, sehingga dasardasar akidah harus terus-menerus ditanamkan pada diri anak agar setiap perkembangan dan pertumbuhannya senantiasa dilandasi oleh akidah yang benar.

b. Pendidikan ibadah, hal ini juga penting bagi pertumbuhan dan perkembangan anak usia dini. Karenanya tata peribadatan menyeluruh sebagaimana termaktub dalam fiqih Islam hendaklah diperkenalkan sedini mungkin dan dibiasakan dalam diri anak sejak usia dini. Hal ini dilakukan agar kelak mereka tumbuh menjadi insan yang benarbenar takwa, yakni insan yang taat melaksanakan segala perintah agama dan taat pula dalam menjauhi segala larangannya.

c. Pendidikan akhlak, dalam rangka mendidik akhlak kepada anak-anak, selain harus diberikan keteladanan yang tepat, juga harus ditunjukkan tentang bagaimana menghormati dan bertata krama dengan orang tua, guru, saudara (kakak dan adiknya) serta bersopan santun dalam bergaul dengan sesama manusia. Alangkah bijaksananya jika para orangtua atau orang dewasa lainnya telah memulai dan menanamkan pendidikan akhlak kepada anak-anaknya sejak usia dini, apa lagi jika dilaksanakan secara terprogram dan rutin. ${ }^{7}$

Dalam rangka mengoptimalkan perkembangan anak dan memenuhi karakteristik anak yang merupakan individu unik, yang mempunyai pengalaman dan pengetahuan yang berbeda, maka perlu dilakukan usaha yaitu dengan memberikan rangsangan-rangsangan, dorongandorongan, dan dukungan kepada anak. Agar para pendidik dapat melakukan dengan optimal maka perlu disiapkan suatu kurikulum yang sistematis. Selain pembentukan sikap dan perilaku yang baik, anak juga memerlukan kemampuan intelektual agar anak siap menghadapi tuntutan masa kini dan masa datang. Sehubungan dengan itu maka program

${ }^{6} \mathrm{M}$. Athiyah Al Abrasy, at-Tarbiyah al-Islāmiyah wa Falasatuhā, (TTp: 'Isa al-Bābi al-Jalabī wa syirkāhu,1969), h. 163.

${ }^{7}$ Mansur, Pendidikan Anak..., h.117. 
pendidikan dapat mencakup bidang pembentukan sikap dan pengembangan kemampuan dasar yang keseluruhannya berguna untuk mewujudkan manusia sempurna yang mampu berdiri sendiri, bertanggung jawab dan mempunyai bekal untuk memasuki pendidikan selanjutnya. Karenanya kurikulum untuk anak usia dini sebaiknya memperhatikan beberapa prinsip. Pertama, berpusat pada anak, artinya anak merupakan sasaran dalam kegiatan pembelajaran yang dilakukan oleh pendidik. Kedua, mendorong perkembangan fisik, daya pikir, daya cipta, sosial emosional, bahasa dan komunikasi sebagai dasar pembentukan pribadi manusia yangh utuh. Ketiga, memperhatikan perbedaan anak, baik perbedaan keadaan jasmani, rohani, kecerdasan dan tingkat perkembangannya. Pengembangan program harus memperhatikan kesesuaian dengan tingkat perkembangan anak (Developmentally Appropriate Program). ${ }^{8}$

Acuan menu pembelajaran pada Pendidikan Anak Usia Dini telah mengembangkan program kegiatan belajar anak usia dini. Program tersebut dikelompokkan dalam enam kelompok usia, yaitu lahir - 1 tahun, $1-2$ tahun, $2-3$ tahun, $3-4$ tahun, $5-6$ tahun dan $5-$ 6 tahun. Masing-masing kelompok usia dibagi dalam enam aspek perkembangan yaitu: perkembangan moral dan nilai-nilai agama, perkembangan fisik, perkembangan bahasa, perkembangan kognitif, perkembangan sosial emosional, dan perkembangan seni dan kreativitas. ${ }^{9}$

Masing-masing aspek perkembangan tersebut dijabarkan dalam kompetensi dasar, hasil belajar dan indikator. Indikator-indikator kemampuan yang diarahkan pada pencapaian hasil belajar pada masing-masing aspek pengembangan, disusun berdasarkan sembilan kemampuan belajar anak usia dini. Kecerdasan linguistic (linguistc intelligence) yang dapat berkembang bila dirancang melalui berbicara, mendengarkan, membaca, menulis, berdiskusi, dan bercerita. Kecerdasan logika-matematika (logico-mathematical intelligence) yang dapat dirangsang melalui kegiatan menghitung membedakan bentuk, menganalisis data, dan bermain dengan benda-benda. Kecerdasan visual-spasial (visual-spatial intelligence) yaitu kemampuan ruang yang dapat dirangsang melalui kegiatan bermain balok-balok dan bentukbentuk geometri melengkapi puzzle, menggambar, melukis, menonton film maupun bermain dengan daya khayal (imajinasi). Kecerdasan musikal (musical intelligence) yang dapat dirangsang melalui irama, nada, berbagai bunyi, dan tepuk tangan. Kecerdasan kinestik (kinesthetic intelligence) yang dirangsang melalui kegiatan-kegiatan seperti melakukan

\footnotetext{
${ }^{8}$ M. Nipan Abdul Halim, Anak Saleh Dambaan Keluarga, (Jakarta: Mitra Pustaka, 2001), h. 25

${ }^{9}$ Depdiknas, Acuan Menu Pembelajaran pada Pendidikan Usia Dini (Pembelajaran Generik), (Jakarta: Depdiknas,2002), h. 21.
} 
gerakan yang teratur, tarian, olahraga, dan terutama gerakan tubuh. Kecerdasan naturalis (naturalist intelligence) yaitu mencintai keindahan dan alam. Kecerdasan ini dapat dirangsang melalui pengamatan lingkungan, bercocok tanam, memelihara binatang, termasuk mengamati fenomena alam seperti hujan, angin, banjir, pelangi, siang malam, panas dingin, bulan dan matahari. Kecerdasan antarpersonal (interpersonal intelligence) yaitu kemampuan untuk melakukan hubungan antar manusia (berkawan) yang dapat dirangsang melalui bermain bersama teman, bekerjasama, bermain peran, dan memecahkan masalah, serta menyelesaikan konflik. Kecerdasan interpersonal, yaitu kemampuan memahami diri sendiri yang dapat dirangsang melalui pengembangan konsep diri, harga diri, mengenal diri sendiri, percaya diri, termasuk kontrol diri dan disiplin. Kecerdasan spiritual (spiritual intelligence) yakni kemampuan mengenal dan mencintai ciptaan Tuhan. Kecerdasan ini dapat dirangsang melalui kegiatan-kegiatan yang diarahkan pada penanaman nilai-nilai moral dan agama. Kecerdasan-kecerdasan tersebut merupakan dasar bagi perumusan kompetensi, hasil belajar dan kurikulum pembelajaran pada anak usia dini.

\section{B. Peran Perempuan dalam Pendidikan Anak Usia Dini}

Secara primordial Allah swt, menciptakan manusia sebagai khalifah di muka bumi. Setiap muslim muslimah mendapat amanah untuk menjadi khalifah sesuai firman Allah swt, Q.S: 2: 30. Mengacu pada ayat tersebut, tidak sepatutnya permpuan muslim berkecimpun dalam satu sektor kehidupan saja, melainkan hendakalah berkiprah dalam berbagai sektor sesuai kemampuan minat, bakat dan potensi yang Allah swt, anugrahkan kepadanya. Aktifitas perempuan muslimah dalam praksis kehidupan adalah mewujudkan keseimbangan kehidupan duniawi dan ukhrawi. Q.S: 28: 77.

Perempuan memiliki hak dan kewajiban yang sama dengan kaum laki-laki dalam menyampaikan amanat kepada mereka yang layak menerima, melakukan advokasi hukum, pelayanan kesehatan, penguatan ekonomi dan pendidikan.

Realisasi memakmurkan bumi secara kelembagaan di bidang pendidikan dan pengembangan ilmu pengetahuan ialah dengan menyelenggarakan pendidikan anak usia dini, TK, SD, SMP, SMA bahkan menyelenggarakan pendidikan tinggi ke seluruh wilayah Indonesia sebagaimana organisasi perempuan Aisyiyah. ${ }^{10}$

George Psacharopoulos dalam Sudarwan Danim menyatakan bahwa perempuan dapat mencapai pendidikan tertinggi, perstasinya dalam sektor usaha sangat luar biasa, jika

\footnotetext{
${ }^{10}$ Suara Aisyiyah, (Ed. Juli: 2015), h. 11.
} 
pendapatan dijadikan indikator. Hasil penelitian menunjukkan bahwa di United Kingdom, rasio pendapatan perempuan sarjana dengan seluruh pekerja adalah 2,6 sedangkan kaum lakilaki hanya 2,3. Di Amerika perempuan yang mnyelesaikan pendidikan terttinggi memperoleh pendapatan rata-rata $40 \%$ lebih tinggi dari pada rata-rata pendapatan kaum laki-laki. Bahakan perempuan yang tidak sempat menyelesaikan pendidikan di perguruan tinggi, penghasilannya $60 \%$ setara dengan dengan laki-laki, bahkan melebihi. ${ }^{11}$

Naisbit dan Aburdene, juga menyatakan bahwa era sekarang disebut dengan era kebangkitan perempuan, tidak hanya pada sektor usaha kecil, akan tetapi juga pada posisiposisi eksekutif, arsitek, pengacara, dan lain-lain. Begitu pula era sekarang dapat disebut dengan era perempuan pencetus budaya terutama dalam sektor pendidikan. ${ }^{12}$

Namun demkian peran publik perempuan tidak selamanya kita harus berkiblat di Barat. Dalam kontek keindonesiaan, menurut Yudi Latif jejak langkah perempuan di ruang publik, Indonesia sesungg8hnya berada di garis perintis, bahkan mendahului negara-negar maju sekalipun.

Sejak pra kolonial, telah tampil tokoh-tokoh perempuan sebagai pemimpin politik dan pemerintahan di berbagai kerajaan seantero nusantara. Mereka adalah rati Sinuhun di Palembang, Dayang Lela di Kalimantan Barat, Daeng Pasuli, Andi Matanang, Siti Aisyah, dan I Madina Daeng Bau dari Sulawesi Selatan, We Tanri Ole dari Ternate, Ratu Nur Ilah, Ratu Nahrasiyah, Laksamana Keuhmalayati, dan Sulthanah Tajul alam, Inayat Syah, Safituddin Syah, dari Aceh, Ratu Shima (kalingga), Pramodhawardhani (Mataram Kuno), Tribhunattunggadewi (Majapahit), Ratu Kalinyamat (jepara) dari Jawa tengah dan Jawa Timut, Ratu Dewata, Ratu Sakti, dan Ratu Nilakendra (Pakuan) dari Jawa Barat.

Dalam gerakan "nasionalismepurba" (archaicnationalism), yang muncum sebagai reaksi perlawanan terdisional terhadap kolonialisme secara lokal dan sporadis, tokoh perempuan jugatampil. Sebutlah nama Cut Nyak Dien dan Cut Meutiah dari Aceh, Martha ChristinaTiahahu dari Maluku, Nyi Ageng Serang dari Jawa Tengah.

Dalam gerakan"nasionalisme tua"(protonationalisme), sebagai manifestasi kesadaran emansipasi modern, tokoh perempuan juga hadir, seperti Raden Ajeng Kartini di Jawa Tengah, Raden Dewi Sartika Dari jawa Barat, Maria Wlanada Maramis dari Silawesi Utara, Hajjah Rangkayo Rasuna Said dari Sumatra barat.

\footnotetext{
${ }^{11}$ Sudarwan Danim, Agenda Pembaharuan Sistem Pendidikan (Cet.I; Pustaka Pelajar: Yogyakarata: 2003), h. 175.

${ }^{12}$ Sudarwan Danim, h. 175.
} 
Dalam gerakan nasionalisme modern, sebagai manifestasi transformasi keasadaran dari ethno-nationalism menuju civic nationalism dalam bingkai kebangsaan Indinesia, tokoh perempuan juga berkiprah. Salah satui tokoh terpenting dari sumpah Pemuda adalah Siti Soendari, perwakilan dari putri Indonesia. Tokoh ini terkenal karena komitmen kebangsaannya.

Akhirnya ketika bangsa Indonesia mulai menyelidiki usaha-usaha persiapan kemerdekaan Indonesia, tokoh-tokoh perempuan juga turut serta. Dalam memperjuangkan dasar negara Pancasila dan rancangan konstitusi Undang-Undang dasar 1945 di BPUBK setidaknya ada dua wakil perempuan, Ny. Maria Ulfa Santoso dan Ny RS Soenaryo Mangoenpoepito.

Dengan begitu bukti-bukti yang meyakinkan tentang perang publik perempuan dalam lintasan panjang sejarah Indonesia, istilah founding fathers tidaklah tepat digunakan dalam kosa kata politik Indonesia. Istilah itu barangkali cocok digunakan di negara semacam Amerika Serikat, yang dalam sejarah politiknya cenderung bersifat maskulin. Hak pilih perempuan di negra tersebut baru diakui setelah Perang Dunia II.

Polical correctness dalam konteks kesetaraan gender di Indonesia telah memiliki landasan historis yang kuat, maka gerakan perempuan di Indonesia mestinya tidak perlu berkiblat ke negara-neghara lain. Kepeloporan dan kebaikan itu tidak selalu ada di luar, tatapi juga bisa ditemukan di dalam negeri kita sendiri. Indonesia tidak selalu menjadi pengekor, tetapi bisa menjadi teladan bagi yang lain. Maslahnya indonesia kerap kali bisa mempelopori dan memulai dengan baik, namun serung tidaka mampu merawat dan mengembangkan warisan-wariasan terbaiknya. Akibatnya, sesuatu yang kita rintis dalam perkembangan lebih lanjut justru kita pandang sebagai sesuatu yang asing.

Apa yang harus dilakukan oleh gerakan-gerakan perempuan di tanah air bukanlah sekedar menuntut peran dengan harapan belas kasih kaum laki-laki, tatapi membuktikan kemapuan dirinya, seperti jalan yang telah ditempuh oleh tokoh-tokoh perempuan Indonesia di masa lampau. Di dalam pembuktian diri, diskriminasi pada akhirnya akan meleleh. ${ }^{13}$

Sehubungan dengan penjelasan di atas, ada beberapa alasan bagi perempuan untuk berpartisipasi aktif dalam sektor publik antara lain adalah:

1. Perempuan adalah managerial yang handal dan penuh perhatian (care), oleh karena itu posisi sekertaris lebih banyak didisi oleh kaum perempuan

\footnotetext{
${ }^{13}$ Yudi Latif, m. Republika.co.id/berita/kolom. Resonasi Rabu 24 April 2013.
} 
2. Perasan yang lebih peka terhadap sesuatu hal sehingga dalam memandang persoalan bisa melihat jauh ke dalam akar masalah yang sebenarnya, perasan yang lebih mendominasinya

3. Multi tasking kemampuan perempuan untuk menjangkau banyak hal dalam waktu yang bersamaan. ${ }^{14}$

Pendidikan anak usia dini adalah kelompok manusia yang berusia 0-6 tahun berdasrkan UUD RI no 202003 tentang Sistem Pendidikan Nasional. Para pakar pendidikan anak, mengatakan bahwa anak usia dini adalah kelompok anak yang dalam proses pertumbuhan dan perkembangan yang bersifat unik, dalam arti memiliki pola pertumbuhan dan perkembangan (koordinasi motorik halus dan kasar), intelegensi (daya pikir, daya cipta, kecerdasan emosi, dan kecerdasan spiritual), sosial emosional (sikap dan perlaku serta agama), bahasa dan komunikasi yang khusus sesuai dengan tingkat pertumbuhan dan perkembangan anak.

Sejalan hubungan dengan penjelasan tersebut, anak sejak dilahirkannya ke dunia ini memiliki empat kebutuhan, yakni kebutuhan untuk perlindungan (security), kebutuhan akan pengalaman baru (new experince), kebutuhan akan mendapatkan tanggapan (response), kebutuhan akan dikenal (recognition). ${ }^{15}$ Berdasarkan kenyataan dan sinergitas dari empat kebutuhan tersebut, maka anak sejak dilahirkan hidup dalam ketergantungan berupa bimbingan dan latihan dari oarang lain, sehingga mencapai tahap kematangan.

Pada saat bersamaan, rasa ketergantungan tersebut, secara kodrati dalam memenuhi rasa ketergantungan tersebut membutuhkan kekuatan yang supra natural. Menurut Thomas, rasa ketergantungan tersebutlah yang menjadi awal lahirnya jiwa keagamaan pada diri anak manusia. Kebutuhan keagamaan merupakan kebutuhan yang sangat asasi bagi anak manusia sebagai indikasi bahwa manusia adalah makhluk yang sempurna dan mulia. Karena kesempurnaan dan kemuliaan hanya dapat diraih melalui petunjuk-petunjuk agama.

Dalam rangka menumbuhkan dan melanggengkan jiwa keagamaan pada diri anak manusia terutama pada anak usia dini memerlukan pihak lain untuk dapat menumbuhkan dan mengembangkan jiwa keagamaan tersebut melalui pembinaan dan pelatihan secara intensif melalui jalur pendidikan formal yang dikenal dengan Pendidikan Anak Usia Dini (PAUD) yang terlaksana di Taman Kanak-Kanak (TK). Dalam UUD RI No. 20 tahun 2003 tentang sistem pendidikan Nasional pasal 28, menekankan bahwa Taman Kanak-Kanak merupakan

\footnotetext{
${ }^{14}$ www.salimah.or.id/2011 Dunia Perempuan/ kajian perempuan/ Peran Publik dan Sosial Perempuan bagi kaumnhya.

15 Ibid.
} 
pendidikan anak usia dini yang sangat strategis dalam pengembanhan sumber daya manusia Indonesia di masa depan. ${ }^{16}$

Sementara secara sosio historis peranan perempuan dalam pendidikan anak usia dini telah terbukti dengan jelas bahwa melalui tangan lembutnya menjadi pihak yang terdepan dalam pendidikan anak usia dini. Oleh karena itu dalam ajaran Islam, perempuan sebelum menjadi operator pendidikan usia dini terlebih dahulu, pendidikan bagi anak perempuan sangat diperhatikan. Sebagaimana sabda Rasulullah saw, "barang siapa yang memiliki anak perempuan lalu ia mendidiknya dan membinanya secara baikdan memberinya makanan apa yang diberikan Allah kepadanya, maka si anak akan menjadi pelindungnya dari apai neraka dan akan menghantaarknnya menuju syurga." Mengingat perempuan adalah pencipta dan pembentuk masyarakat masa depan.

Perempuan dalam Islam merupakan cerminan eksistensi Islam. Bahkan dalam literatur keagamaan dikenal dengan ungkapan al-mar'ah 'imaad al- Bilaad. Secara alamiah perempuan diciptakan untuk melahirkan, membina dan mengasuh anak, mengajarkan anak tentang sopan santun yang berdasarkan norma-norma agama. Meskipun di masa modern ini terdapat perempuan yang keliru dalam memahami konsep modernitas itu sendiri dengan mengabaikan peran utamanya sebagai perempuan. Sementara dalam ajaran Islam betapa eksistensi kaum perempuan sangat terhorhormat, yang dilegitimasi secara teologis mengenai hak-hak perempuan dalam aspek domestik demikian pula dalam aspek publik.

Perempuan diibaratkan tiang negara bilamana baik perempuannya, maka baik pula negaranya, demikian sebailknya. Sementara perempuan menurut Fadhil al-Jamali ada dua tipe perempuan yakni, pertama, perempuan yang kurang pengertian dan pengetahuan tentang modernitas. Kedua, perempuan yang modern yang sering meninggalkan pekerjaan rumah tangganya. kebutuhan Termasuk pengalaman-pengalaman yang diterimanya dari lingkungan sekitarnya persoalan keagamaan pada diri anak.

Beberapa pendapat yang terkait dengan anak bahwa sejak dilahirkannya anak bukanlah sebagai makhluk yang relegius, karena anak hanya dipandang sebagai makhluk dari aspek biologis bukan karena makhluk dari segi kejiwaan.

Dalam pandangan Islam, segala sesuatu yang dilaksanakan, tentulah memiliki dasar hukum baik itu yang berasal dari dasar naqliyah maupun dasar aqliyah. Begitu juga halnya dengan pelaksanakan pendidikan pada anak usia dini. Berkaitan dengan pelaksanaan pendidikan anak usia dini, dapat dibaca firman Allah berikut ini:

${ }^{16}$ Suara Aisyiyah Majalah Agama dan Wanita, Ed. 88. Juli 2011, h.28. 
Berdasarkan ayat tersebut di atas, dipahami bahwa anak lahir dalam keadaan lemah tak berdaya dan tidak mengetahui (tidak memiliki pengetahuan) apapun. Akan tetapi Allah membekali anak yang baru lahir tersebut dengan pendengaran, penglihatan dan hati nurani (yakni akal yang menurut pendapat yang sahih pusatnya berada di hati). Menurut pendapat yang lain adalah otak. Dengan itu manusia dapat membedakan di antara segala sesuatu, mana yang bermanfaat dan mana yang berbahaya. Kemampuan dan indera ini diperoleh seseorang secara bertahap, yakni sedikit demi sedikit. Semakin besar seseorang maka bertambah pula kemampuan pendengaran, penglihatan, dan akalnya hingga sampailah ia pada usia matang dan dewasanya. ${ }^{17}$ Dengan bekal pendengaran, penglihatan dan hati nurani (akal) itu, anak pada perkembangan selanjutnya akan memperoleh pengaruh sekaligus berbagai didikan dari lingkungan sekitarnya. Hal ini pula yang sejalan dengan sabda Rasul berikut ini:

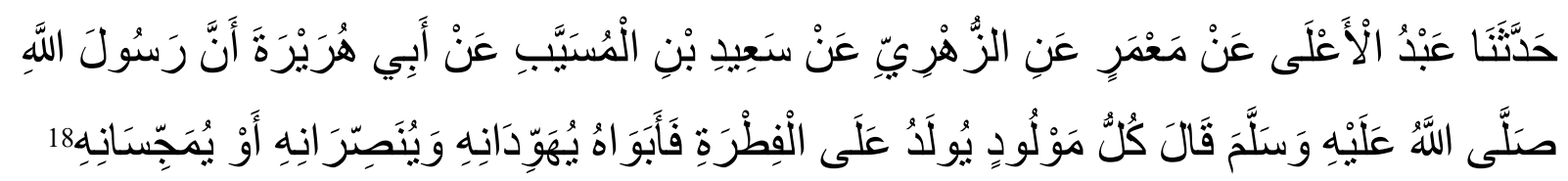

Artinya: "Setiap anak dilahirkan dalam keadaan fitrah, maka kedua orang tuanyalah yang menjadikan anak tersebut beragama Yahudi, Nasrani ataupun Majusi”.(HR. Bukhari, Abu Daud, Ahmad)

Meskipun anak lahir dalam keadaan lemah tak berdaya serta tidak mengetahui apaapa, tetapi ia lahir dalam keadaan fitrah, yakni suci dan bersih dari segala macam keburukan. Karenanya untuk memelihara sekaligus mengembangkan fitrah yang ada pada anak, orang tua berkewajiban memberikan didikan positif kepada anak sejak usia dini atau bahkan sejak lahir yang diawali dengan mengazankannya. Hal ini dikarenakan pada prinsipnya fitrah manusia menuntut pembebasan dari kemusyrikan dan akibat-akibatnya yang dapat menyeret manusia kepada penyimpangan watak dan penyelewengan serta kesesatan di dalam berfikir, berencana dan beraktivitas. Bagi manusia kepala merupakan pusat penyimpanan informasi alat indera yang mengatur semua eksistensi dirinya, baik psikologis maupun biologis. Indera pendengaran, penglihatan, penciuman dan indera perasaan diatur oleh kepala. Tatkala azan berikut kalimah yang dikandungnya, yaitu kalimah Takbir dan kalimah Tauhid, meyentuh pendengaran si bayi, maka kalimah azan tersebut ibarat tetesan air jernih yang berkilauan ke dalam telinganya, sesuai dengan fitrah dirinya. Pada waktu itu si bayi belum dapat merasakan apa-apa, hanya kesadarannya dapat merekam nada-nada dan bunyi-bunyi kalimah azan yang

\footnotetext{
${ }^{17} \mathrm{Al}$ Imam Abul Fida Ismail Ibnu Kasir Ad-Dimasyqi, Tafsir Al Qur’an al-'Ażīm, terjemahan Bahrum Abu Bakar, Tafsir Ibnu Kaśīr juz 14, (Bandung: Sinar Baru Algesindo, 2003), h. 216.

${ }^{18} \mathrm{Abu}$ Abdullah ibn Muhammad Isma'il al-Bukhari, Shahih Bukhri Juz I, (Riyadh: Idaratul Bahtsi Ilmiah,tt), h. 25.
} 
diperdengarkan kepadanya. Kalimah terebut dapat mencegah jiwanya dari kecenderungan kemusyrikan serta dapat memelihara dirinya dari kemusyrikan. Demikian pula kalimah azan seolah-olah melatih pendengaran manusia (dalam hal ini anak bayi/usia dini) agar terbiasa mendegarkan panggilan nama yang baik, sehingga hal ini menuntut para orang tua untuk memberi (menamai) anaknya dengan nama yang baik serta memiliki makna yang baik pula. Hal ini sejalan dengan sabda Rasul:

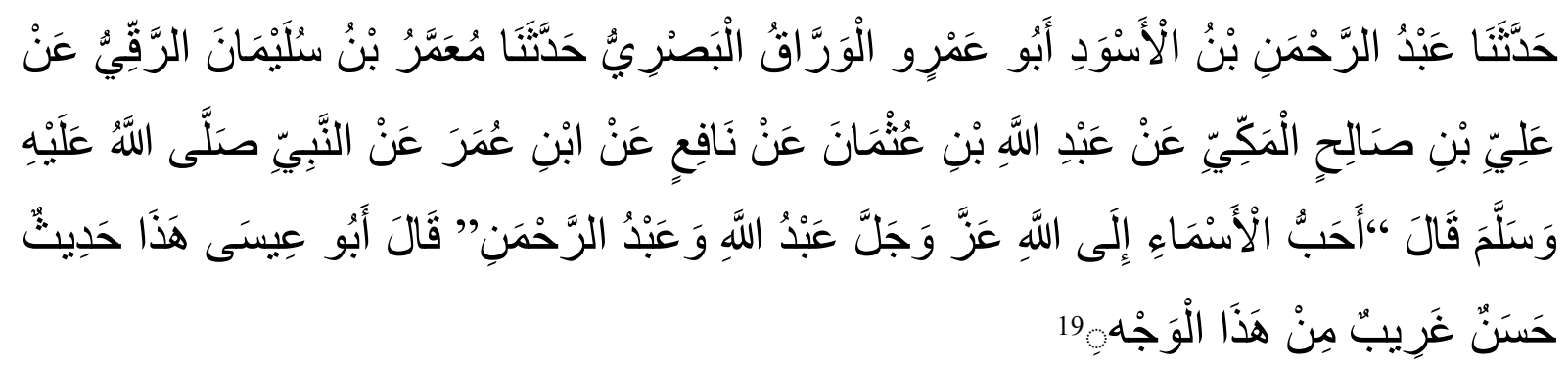

Artinya: "Nama yang paling disukai Allah adalah Abdullah dan Abdurrahman".(HR. At-Tirmizi)

Nama yang indah sesungguhnya tidak hanya sekedar nama atau panggilan, tetapi sesungguhnya merupakan cerminan tentang adanya pujian atau do'a, harapan atau gambaran semangat dan dambaan indah kepada anak-anaknya.

Dalam mendukung perkembangan anak pada usia-usia selanjutnya, termasuk pada usia dini, yang menjadi kewajiban orang tua adalah memberikan didikan positif terhadap anak-anaknya, sehingga anak-anaknya tersebut tidak menjadi/mengikut ajaran Yahudi, Nasrani atau Majusi, melainkan menjadi muslim yang sejati. Mendidik anak dalam pandangan Islam, merupakan pekerjaan mulia yang harus dilaksanakan oleh setiap orang tua, hal ini sejalan dengan sabda Rasul:

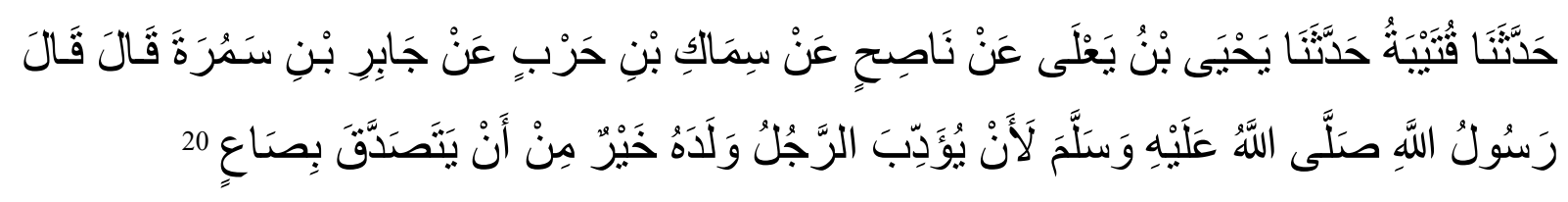

"Seseorang yang mendidik anaknya adalah lebih baik daripada ia bersedekah dengan satu sha'(R. Tirmidzi)

Dalam pandangan Islam anak merupakan amanah di tangan kedua orang tuanya. Hatinya yang bersih merupakan permata yang berharga, lugu dan bebas dari segala macam ukiran dan gambaran. Ukiran berupa didikan yang baik akan tumbuh subur pada diri anak, sehingga ia akan berkembang dengan baik dan sesuai ajaran Islam, dan pada akhirnya akan

\footnotetext{
${ }^{19}$ Imam al-Hafidz Abi 'Abbas Muhammad ibn 'Isa ibn Saurah at-Tirmiżi, Sunan at-Tirmiżi al-Jami’us Şahih, juz 4, (Semarang: Toha Putra,tt,). h. 216.

${ }^{20}$ Imam al-Hafidz Abi ‘Abbas Muhammad ibn 'Isa ibn Saurah at-Tirmiżi, Sunan at-Tirmiżi al-Jami'us Şahih, juz 3, (Semarang: Toha Putra,tt,). h 227
} 
meraih kebahagiaan di dunia dan di akhirat. Jika anak sejak dini dibisakan dan dididik dengan hal-hal yang baik dan diajarkan kebaikan kepadanya, ia akan tumbuh dan berkembang dengan baik dan akan memperoleh kebahagiaan serta terhindar dari kesengaraan/siksa baik dalam hidupnya di dunia maupun di akhirat kelak. Hal ini senada dengan firman Allah dalam QS. Al Tahrim: 6 yang artinya:

"Hai orang-orang yang beriman, peliharalah dirimu dan keluargamu dari api neraka yang bahan bakarnya adalah manusia dan batu; penjaganya malaikat-malaikat yang kasar, yang keras, yang tidak mendurhakai Allah terhadap apa yang diperintahkanNya kepada mereka dan selalu mengerjakan apa yang diperintahkan.

Terhadap ayat ini Ibnu Kasir dalam tafsirnya menjelaskan, bahwa ayat ini menganjurkan kepada setiap individu muslim bertakwa kepada Allah dan perintahkanlah kepada keluargamu untuk bertakwa kepada Allah. Ibnu Kasir menjelaskan bahwa Qatada mengatakan bahwa engkau perintahkan mereka untuk taat kepada Allah dan engkau cegah mereka dari perbuatan durhaka terhadapNya, dan hendaklah engkau tegakkan terhadap mereka perintah Allah dan engkau anjurkan mereka untuk mengerjakannya serta engkau bantu mereka untuk mengamalkannya. Jika engkau melihat di kalangan keluargamu suatu perbuatan maksiat kepada Allah, maka engkau harus cegah mereka darinya dan engkau larang mereka melakukannya. Hal yang sama juga dikemukakan Ad-Dahlak dan Muqatil, bahwa sudah merupakan suatu kewajiban bagi seorang muslim mengajarkan kepada keluarganya, baik dari kalangan kerabatnya ataupun budak-budaknya, hal-hal yang difardukan oleh Allah dan mengajarkan kepada mereka hal-hal yang dilarang oleh Allah yang harus mereka jauhi. ${ }^{21}$

Berdasarkan ayat tersebut, dipahami bahwa orang tua memiliki kewajiban untuk memelihara diri dan keluarga (anak-anaknya) dari siksaan api neraka. Cara yang dapat dilakukan oleh orang tua ialah mendidiknya, membimbingnya dan mengajari akhlak-akhlak yang baik. Kemudian orang tua harus menjaganya dari pergaulan yang buruk, dan jangan membiasakannya berfoya-foya, jangan pula orang tua menanamkan rasa senang bersolek dan hidup dengan sarana-sarana kemewahan pada diri anak, sebab kelak anak akan menyianyiakan umurnya hanya untuk mencari kemewahan jika ia tumbuh menjadi dewasa, sehingga ia akan binasa untuk selamanya. Akan tetapi seharusnya orang tua sejak dini mulai

\footnotetext{
${ }^{21}$ Ibnu Kasir, Tafsir Al Qur’an al- Ażīm juz 28..., h. 416.
} 
mengawasi pertumbuhannya dengan cermat dan bijaksana sesuai dengan tuntutan pendidikan Islam. $^{22}$

Dari uraian di atas kiranya dapat disebutkan bahwa tujuan pendidikan anak usia dini dalam pandangan Islam adalah memelihara, membantu pertumbuhan dan perkembangan fitrah manusia yang dimiliki anak, sehingga jiwa anak yang lahir dalam kondisi fitrah tidak terkotori oleh kehidupan duniawi yang dapat menjadikan anak sebagai Yahudi, Nasrani atau Majusi. Atau dengan kata lain bahwa pendidikan anak usia dini dalam pendidikan Islam bertujuan untuk menanamkan nilai-nilai keislaman kepada anak sejak dini, sehinga dalam perkembangan selanjutnya anak menjadi manusia muslim yang kāffah, yang beriman dan bertaqwa kepada Allah SWT. Hidupnya terhindar dari kemaksiatan, dan dihiasi dengan ketaatan dan kepatuhan serta oleh amal soleh yang tiada hentinya. Kondisi seperti inilah yang dikehendaki oleh pendidikan Islam, sehingga kelak akan mengantarkan peserta didik pada kehidupan yang bahagia di dunia maupun di akhirat.

\section{PENUTUP}

Dari uraian tersebut dapat ditarik kesimpulan bahwa:

1. Anak usia dini adalah kelompok manusia yang berusia 0-6 tahun berdasrkan UUD RI no 202003 tentang Sistem Pendidikan Nasional. Para pakar pendidikan anak, mengatakan bahwa anak usia dini adalah kelompok anak yang dalam proses pertumbuhan dan perkembangan yang bersifat unik, dalam arti memiliki pola pertumbuhan dan perkembangan (koordinasi motorik halus dan kasar), intelegensi (daya pikir, daya cipta, kecerdasan emosi, dan kecerdasan spiritual), sosial emosional (sikap dan perlaku serta agama), bahasa dan komunikasi yang khusus sessuai dengan tingkat pertumbuhan dan perkembangan anak. Pendidikan anak Usia Dini, menurut Peraturan Pemerintah RI nomor 27 tahun 1990, tentang pendidikan pra sekolah, bahwa kegiatan belajar anak usia dini meliputi aspek, moral, agama, disiplin, kemampauan berbahasa, daya pikir, daya cipta,, emosi, kemammpuan bermasyarakat, sosial, keterampilan.

2. Peran Perempuan dalam pendidikan Anak Usia Dini merupakan cerminan eksistensi Islam. Bahkan dalam literatur keagamaan dikenal dengan ungkapan al-mar'ah 'imaad al- Bilaad. Secara alamiah perempuan diciptakan untuk melahirkan, membina dan mengasuh anak, mengajarkan anak tentang sopan santun yang berdasarkan normanorma agama. Semua ini sepatutnya didikkan kepada anak sejak usia dini dan yang

22 Muhammad Ali Quthb, Auladuna fi Dlau-it Tarbiyyatil Islamiyyah, terjemahan Bahrum abu Bakar Ihsan, (Bandung: Diponegoro,1988), h. 59. 
paling berpengaruh adalah ibu dan guru PAUD yang umumnya perempuan. Meskipun di masa modern ini terdapat perempuan yang keliru dalam memahami konsep modernitas itu sendiri dengan mengabaikan peran utamanya sebagai perempuan. Sementara dalam ajaran Islam betapa eksistensi kaum perempuan sangat terhorhormat, yang dilegitimasi secara teologis mengenai hak-hak perempuan dalam aspek domestik demikian pula dalam aspek publik.

\section{DAFTAR RUJUKAN}

Al Abrasy, M. Athiyah. at-Tarbiyah al-Istāmiyah wa Falasatuhā, (TTp: 'Isa al-Bābi al-Jalabī wa syirkāhu, 1969 .

Abu Abdullah ibn Muhammad Isma'il al-Bukhari, Shahih Bukhri Juz I, Riyadh: Idaratul Bahtsi Ilmiah, tt).

Al Imam Abul Fida Ismail Ibnu Kasir Ad-Dimasyqi, Tafsir Al Qur’an al-‘Ażīm, terjemahan

Bahrum Abu Bakar, Tafsir Ibnu Kaśīr juz 14, Bandung: Sinar Baru Algesindo, 2003.

Danim, Sudarwan. Agenda Pembaharuan Sistem Pendidikan Cet.I; Pustaka Pelajar: Yogyakarata: 2003

Depdiknas, Acuan Menu Pembelajaran pada Pendidikan Usia Dini (Pembelajaran Generik), (Jakarta: Depdiknas,2002

Imam al-Hafidz Abi 'Abbas Muhammad ibn 'Isa ibn Saurah at-Tirmiżi, Sunan at-Tirmiżi alJami’us Şahih, juz 4, Semarang: Toha Putra,tt.

Imam al-Hafidz Abi 'Abbas Muhammad ibn 'Isa ibn Saurah at-Tirmiżi, Sunan at-Tirmiżi alJami’us Şahih, juz 3, Semarang: Toha Putra,tt.

Latif, M. Yudi. Republika.co.id/berita/kolom. Resonasi Rabu 24 April 2013.

Mansur, Pendidikan anak Usia Dini Cet. II; Pustaka Pelajar: Yogyakarta: 2007

Quthb, Muhammad Ali. Auladuna fi Dlau-it Tarbiyyatil Islamiyyah, terjemahan Bahrum abu Bakar Ihsan, Bandung: Diponegoro,1988.

Shihab, Quraish Lentera Al-Quran Kisah dan Hikmah Kehidupan Cet.I; Mizan Pustaka: Bandung: 2008.

Suara Aisyiyah Majalah Agama dan Wanita, Ed. 88. Juli 2011

Suara Aisyiyah, Ed. Juli; 2015

Suara Aisyiyah, Ed.7: 2015

Tafsir, Ahmad. Ilmu Pendidikan dalam Perspektif Islam Cet.III; Remaja Rosda Karya: Bandung: 2000

www.salimah.or.id/2011 Dunia Perempuan/ kajian perempuan/ Peran Publik dan Sosial Perempuan bagi kaumnhya. 